\title{
Bifidobacterium tsurumiense sp. nov., from hamster dental plaque
}

Correspondence

Masaaki Okamoto

okamoto-m@tsurumi-u.ac.jp

\author{
Masaaki Okamoto, ${ }^{1}$ Yoshimi Benno, ${ }^{2}$ Kai-P Leung ${ }^{3}$ and Nobuko Maeda ${ }^{1}$ \\ ${ }^{1}$ Tsurumi University, School of Dental Medicine, Tsurumi, Yokohama, Kanagawa 230-8501, Japan \\ ${ }^{2}$ Microbe Division/Japan Collection of Microorganisms, RIKEN BioResource Center, Wako, Saitama \\ 351-0198, Japan \\ ${ }^{3}$ US Army Dental and Trauma Research Detachment, Great Lakes, IL 60088, USA
}

Bifidobacteria are Gram-positive, anaerobic, non-motile, non-spore-forming bacteria that are prevalent within the gastrointestinal tracts of humans and animals (Mikkelsen et al., 2003). A role in human gut health has been recognized for members of the genus Bifidobacterium: they serve as probiotic micro-organisms, improving the microbial balance of intestinal flora (Caglar et al., 2005). To date, bifidobacteria have not been found to cause human disease, although three species of bifidobacteria have been isolated from dental caries (Becker et al., 2002; Beighton, 2005; Crociani et al., 1996; Jian \& Dong, 2002; Love \& Jenkinson, 2002; Munson et al., 2004). Phenotypic characteristics of members of the genus Bifidobacterium are as follows: a high DNA G + C content, an absolute requirement for anaerobic growth conditions, fructose-6-phosphate phosphoketolase (F6PPK) activity and the production of acetic and lactic acids (at a molar ratio of $3: 2$ ) as end products of glucose fermentation (Scardovi, 1986).

During our studies on experimental dental diseases from 1987 to 1997, we collected a number of oral isolates that have not been identified to genus level. Three of these isolates, which we have identified as Bifidobacterium-like organisms, grew under aerobic conditions, and their DNA $\mathrm{G}+\mathrm{C}$ contents were slightly lower $(53 \mathrm{~mol} \%)$ than those

Abbreviation: F6PPK, fructose-6-phosphate phosphoketolase.

The GenBank/EMBL/DDBJ accession number for the 16S rRNA and hsp60 gene sequences of strain $\mathrm{OMB}_{115^{\top}}$ are $\mathrm{AB} 241106$ and AB241108, respectively.

A neighbour-joining phylogenetic tree based on partial hsp60 gene sequences is available as supplementary material with the online version of this paper. of members of the genus Bifidobacterium. Here, we report the taxonomic study of these novel isolates obtained from dental plaque from golden hamsters fed with a highcarbohydrate diet. The reference strains used in this study, Bifidobacterium boum JCM $1211^{\mathrm{T}}$, Bifidobacterium thermacidophilum JCM $11165^{\mathrm{T}}$, Bifidobacterium indicum JCM $1302^{\mathrm{T}}$ and Bifidobacterium dentium JCM $1195^{\mathrm{T}}$, were obtained from the Japan Collection of Microorganisms (RIKEN BioResource Center). These organisms were maintained on Brucella HK agar plates (Kyokuto) in an Anaero Box (Forma Scientific) under an atmosphere comprising $\mathrm{N}_{2} / \mathrm{CO}_{2} / \mathrm{H}_{2} \quad(80: 10: 10)$ at $37{ }^{\circ} \mathrm{C}$. Bacterial specimens were collected from dental plaque samples from hamsters that had been given a high-carbohydrate diet (D\#2000; Jordan et al., 1969) for 6 weeks. Diluted aliquots of the plaque samples were inoculated onto CFAT agar and incubated in an anaerobic box at $37{ }^{\circ} \mathrm{C}$ for 4 days. The CFAT agar used was a selective medium for human actinomycetes (Zylber \& Jordan, 1982), its composition $\left(1^{-1}\right)$ being as follows: trypticase soy broth (BBL Microbiology Systems), $30 \mathrm{~g}$; glucose, $5 \mathrm{~g}$; agar, $15 \mathrm{~g}$; cadmium sulfate, $13 \mathrm{mg}$; sodium fluoride, $85 \mathrm{mg}$; neutral acriflavin, $1.2 \mathrm{mg}$; potassium tellurite, $2.5 \mathrm{mg}$; basic fuchsin, $1.3 \mathrm{mg}$; defibrinated sheep blood, $50 \mathrm{ml}$.

For chromosomal DNA preparations, culture cells were incubated with lysozyme (Seikagaku Kogyo) at $4 \mathrm{mg} \mathrm{ml}^{-1}$, $\mathrm{N}$-acetylmuramidase SG (Seikagaku Kogyo) at $50 \mathrm{\mu g} \mathrm{ml}^{-1}$ and $1000 \mathrm{U}$ achromopeptidase (Wako Pure Chemical Industry) for $3 \mathrm{~h}$ at $37^{\circ} \mathrm{C}$. Bacterial DNA was extracted according to the methods of Marmur \& Doty (1961). The DNA concentration was determined spectrophotometrically from the $A_{260}$ and the purity of the samples was 
estimated by determining the $A_{260} / A_{280}$ ratio. HPLC was used to determine the DNA G+C content (Ezaki et al., 1990). For this purpose, the DNA preparation $[1 \mathrm{mg}(\mathrm{ml}$ distilled water $)^{-1}$ ] was denatured at $100{ }^{\circ} \mathrm{C}$ for $10 \mathrm{~min}$. After rapid cooling in an ice bath, the denatured DNA was digested with $0.05 \mathrm{U}$ nuclease $\mathrm{P} 1$ (Yamasa Shoyu) in $40 \mathrm{mM}$ sodium acetate buffer containing $0.2 \mathrm{mM} \mathrm{ZnCl}_{2}$ at $50{ }^{\circ} \mathrm{C}$ for $1 \mathrm{~h}$. The hydrolysates and a standard solution of deoxyribonucleotide monophosphates (dAMP, dCMP, dGMP and dTMP; Yamasa Shoyu) were subjected to separation by HPLC (L-6200; Hitachi) with a C18 column and eluted with

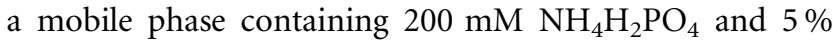
$\mathrm{CH}_{3} \mathrm{CN}$; nucleic acids were detected at $260 \mathrm{~nm}$.

The partial 16S rRNA genes of strains OMB115 ${ }^{\mathrm{T}}$, OMB118 and OMB120 were amplified by PCRs using universal primers 27F and 1492R (Weisburg et al., 1991). The partial $h s p 60$ gene sequences used were highly representative of the whole $h s p 60$ gene, as described in the phylogenetic studies reported by Jian \& Dong (2002). The sequences of the forward (MO-157) and reverse (MO-158) primers used for the PCR amplification of the $h s p 60$ genes were $5^{\prime}$ CTGGTGAAGGAGGTCGCCAA- ${ }^{\prime}$ and $5^{\prime}$-CCATATCCTGCAGCATAGCCTT-3', respectively. These primers were designed from the consensus sequences of Bifidobacterium adolescentis, Bifidobacterium animalis, Parascardovia denticolens and Scardovia inopinata $h s p 60$ genes that are available in the GenBank database. The PCR mixture consisted of $1 \mu \mathrm{l}$ DNA (approx. $50 \mathrm{ng}$ ), $50 \mathrm{mM} \mathrm{KCl}$, $10 \mathrm{mM}$ Tris/HCl (pH 8.3), $1.5 \mathrm{mM} \mathrm{MgCl} 2,200 \mu \mathrm{M}$ each dNTP (Roche Diagnostics), 2 U Taq DNA polymerase (Roche Diagnostics) and $0.5 \mu \mathrm{M}$ each primer. Thirty thermal cycles were performed: each cycle consisted of denaturation at $95{ }^{\circ} \mathrm{C}$ for $30 \mathrm{~s}$, followed by annealing at $60{ }^{\circ} \mathrm{C}$ for $0.5 \mathrm{~min}$ (for $16 \mathrm{~S}$ rRNA gene) or at $45{ }^{\circ} \mathrm{C}$ for $0.5 \mathrm{~min}$ (for the $h s p 60$ gene) and then elongation at $72{ }^{\circ} \mathrm{C}$ for $1.5 \mathrm{~min}$. The predicted PCR products, a $528 \mathrm{bp} h s p 60$ DNA fragment within positions 304-831 of the Escherichia coli K-12 hsp60 gene and a 1455 bp DNA fragment for the rRNA gene, were obtained.

The PCR-amplified 16S rRNA and $h s p 60$ genes from these isolates were purified using a MinElute Reaction Cleanup kit (Qiagen). Cycle-sequencing reactions were performed using an ABI PRISM Dye Terminator cycle sequencing ready reaction kit (Applied Biosystems) and an ABI PRISM 3100 Genetic Analyzer (Applied Biosystems). The calculation of pairwise 16S rRNA and hsp60 gene sequence similarities was achieved using the EzTaxon server (http:// www.eztaxon.org/; Chun et al., 2007). Nucleotide substitution rates ( $K_{\text {nuc }}$ values) were calculated (Kimura \& Ohta, 1972) and phylogenetic trees were constructed using the neighbour-joining method (Saitou \& Nei, 1987). The topology of the trees was evaluated by performing a bootstrap analysis of the sequence data using CLUSTAL W, version 1.83 (Thompson et al., 1994).

We constructed a phylogenetic tree based on a total of 36 partial 16S rRNA gene sequences including those of members of the genus Bifidobacterium and of related genera. The tree was rooted using E. coli K-12 (Fig. 1). Strain OMB $115^{\mathrm{T}}$ showed a $16 \mathrm{~S}$ rRNA gene sequence that was similar to those of B. boum, B. thermacidophilum, Bifidobacterium thermophilum, Bifidobacterium coryneforme, Bifidobacterium asteroides and B. indicum. The levels of similarity for the partial $16 \mathrm{~S}$ rRNA gene sequence of strain $\mathrm{OMB} 115^{\mathrm{T}}$ in relation to the type strains of $B$. boum, $B$. thermophilum, B. indicum and B. thermacidophilum were 96.1, 95.2, 94.9 and $94.2 \%$, respectively.

$16 \mathrm{~S}$ rRNA gene sequences have been the primary resource for phylogenetic studies and sequence-based taxonomy

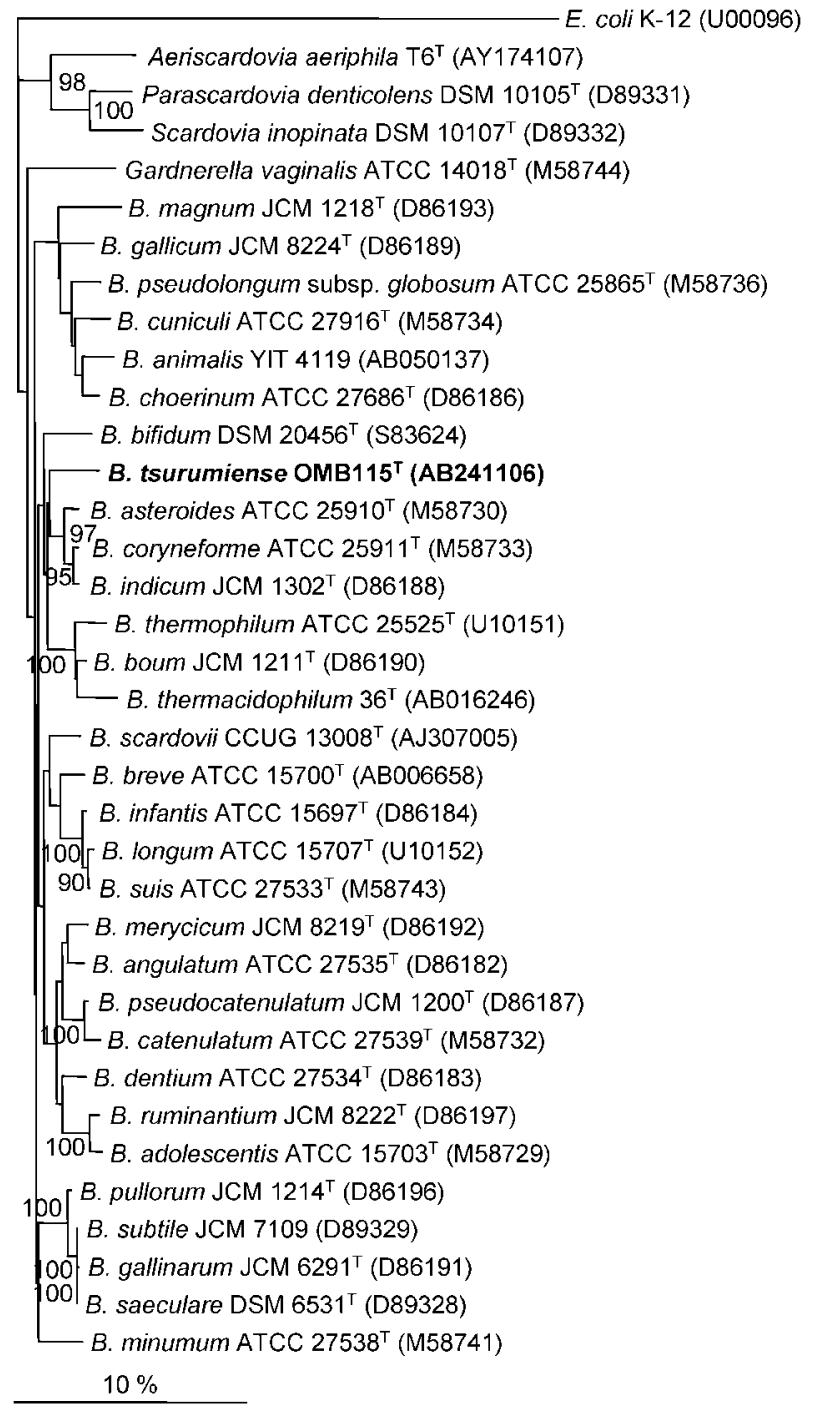

Fig. 1. Neighbour-joining phylogenetic tree, based on partial $16 \mathrm{~S}$ rRNA gene sequences, for strain $\mathrm{OMB} 115^{\top}$ and related taxa. The tree was rooted with $E$. coli $\mathrm{K}-12$. Bootstrap percentages (based on 1000 replicates) are shown at nodes. GenBank accession numbers are given in parentheses. Bar, 10\% difference in nucleotide sequence. 
(Miyake et al., 1998; Sakata et al., 2006; Weisburg et al., 1991; Woese et al., 1990). In recent years, several housekeeping genes, such as heat-shock protein genes (the $h s p 60$ gene; also known as groEL or cpn60, groES and $d n a K$ genes), have been used for taxonomic studies of bifidobacterial species (Delcenserie et al., 2005; Jian et al., 2001; Simpson et al., 2004; Ventura et al., 2004, 2005; Zhu et al., 2003). Bifidobacterium inopinatum and B. denticolens, isolated from human dental caries, were transferred to $S$. inopinata and Parascardovia denticolens, respectively, on the basis of taxonomic studies involving $h s p 60$ sequences (Jian \& Dong, 2002).

Likewise, we also constructed a phylogenetic tree based on a total of 36 sequences of $h s p 60$ genes including those of members of the genus Bifidobacterium and of related genera (see Supplementary Fig. S1 in IJSEM Online). Strain OMB $115^{\mathrm{T}}$ showed $h$ sp60 gene sequence similarities of 80.6, 79.7 and $79.3 \%$ with respect to the type strains of $P$. denticolens, Gardnerella vaginalis and S. inopinata, respectively. The levels of partial $h s p 60$ gene sequence similarity between strain $\mathrm{OMB} 115^{\mathrm{T}}$ and the type strains of Bifidobacterium pullorum, Bifidobacterium merycicum and B. boum were higher $(83.7,83.1$ and $81.2 \%$, respectively). However, the levels of $h s p 60$ gene sequence similarity among Bifidobacterium species were much lower than those for $16 \mathrm{~S}$ rRNA gene sequences. Therefore, in this case, $16 \mathrm{~S}$ rRNA gene sequences were more useful than $h s p 60$ gene sequences for determining the phylogeny of strain $\mathrm{OMB} 115^{\mathrm{T}}$. It is likely that the similarity values observed for the $h s p 60$ gene among different Bifidobacterium species were the result of lateral transfer.

For the determination of phenotypic characteristics, API 50 CHL, API Rapid ID 32A and API ZYM tests were performed (in triplicate) using the methods recommended by the manufacturer (bioMérieux). Cells from agar plates were suspended in sterile water, inoculated onto the test strips and incubated in air for $4 \mathrm{~h}$ (for API Rapid ID 32A and API ZYM) or in an anaerobic box (for API $50 \mathrm{CHL}$ ) at $37{ }^{\circ} \mathrm{C}$ for 48 h. F6PPK activity was determined according to the method described by Scardovi (1986). Cell-wall peptidoglycan was prepared and hydrolysed using the methods of Kawamoto et al. (1981). The cell-wall amino acids were determined with an automatic amino acid analyser (model 835; Hitachi). Separation of amino acids was performed using previously published procedures (Einarsson et al., 1987).

Table 1 shows the major characteristics of strain OMB $115^{\mathrm{T}}$ and related bacteria. Strain OMB $115^{\mathrm{T}}$ was found to be a Gram-positive, facultative anaerobe comprising short and irregularly shaped rods, was positive for F6PPK and was negative for catalase and oxidase. Of members of the family Bifidobacteriaceae, Aeriscardovia aeriphila, Bifidobacterium psychraerophilum, Bifidobacterium scardovii and G. vaginalis have been reported to be able to grow under aerobic conditions (Hoyles et al., 2002; Simpson et al., 2004; van Esbroeck et al., 1996). B. boum and B. thermophilum have been reported as having microaerophilic profiles (Kawasaki et al., 2006). The optimal temperature for growth of strain OMB $115^{\mathrm{T}}$ was $37^{\circ} \mathrm{C}$; growth also occurred at 25 and $45^{\circ} \mathrm{C}$. The strain was able to grow on lactobacillus selective agar (LBS agar; Becton Dickinson). In contrast, growth of $S$. inopinata, $P$. denticolens and other members of the Bifidobacteriaceae was inhibited on this selective medium. The DNA G $+\mathrm{C}$ content of strain OMB $115^{\mathrm{T}}$ was $53 \mathrm{~mol} \%$, which is consistent with those of $P$. denticolens and $A$. aeriphila (Simpson et al., 2004) but slightly lower than values reported previously for the genus Bifidobacterium (5867 mol\%) (Crociani et al., 1996; Simpson et al., 2004; Zhu et al., 2003). However, the DNA G+C content of strain $\mathrm{OMB}_{115^{\mathrm{T}}}$ was higher than that of S. inopinata (45 mol\%) (Crociani et al., 1996). Isolates OMB118 and OMB120 showed the same characteristics as strain $\mathrm{OMB} 115^{\mathrm{T}}$.

On the basis of this phylogenetic study using phenotypic characterization and 16S rRNA gene sequence similarity data, strains OMB115 ${ }^{\mathrm{T}}$, OMB118 and OMB120 represent a novel species of the genus Bifidobacterium, for which the name Bifidobacterium tsurumiense sp. nov. is proposed.

\section{Description of Bifidobacterium tsurumiense sp. nov.}

Bifidobacterium tsurumiense (tsu.ru.mi.en'se. N.L. neut. adj. tsurumiense pertaining to Tsurumi University, Yokohama, Japan).

Colonies on Brucella HK blood agar plates are white, rough and slightly convex. Cells are short rods or coccoid when grown on Brucella $\mathrm{HK}$ blood agar under anaerobic conditions for $24 \mathrm{~h}$. Cells are Gram-positive, F6PPKpositive, catalase- and oxidase-negative. Facultatively anaerobic. Growth occurs at 25 and $45{ }^{\circ} \mathrm{C}$; optimal temperature for growth is $37^{\circ} \mathrm{C}$. Growth also occurs on LBS and CFAT agars. End products of glucose fermentation are acetic and lactic acids at a molar ratio of $3: 2$. The DNA G $+C$ content is $53 \mathrm{~mol} \%$. L-Arabinose, D-ribose, D-xylose, D-galactose, Dglucose, D-fructose, D-mannose, D-mannitol, methyl $\alpha$-Dglucopyranoside, amygdalin, arbutin, salicin, cellobiose, maltose, D-lactose, melibiose, sucrose, trehalose, raffinose, starch, glycogen, gentiobiose, turanose, gluconate and 2ketogluconate are fermented. Glycerol, erythritol, D-arabinose, L-xylose, D-adonitol, methyl $\beta$-D-xylopyranoside, Lsorbose, L-rhamnose, dulcitol, inositol, D-sorbitol, methyl $\alpha$ D-mannopyranoside, $\mathrm{N}$-acetylglucosamine, inulin, melezitose, xylitol, D-lyxose, D-tagatose, D-fucose, L-fucose, Darabitol, L-arabitol and 5-ketogluconate are not fermented. Positive for aesculin hydrolysis, $\alpha$-galactosidase, $\beta$-galactosidase, $\alpha$-glucosidase, $\beta$-glucosidase, $\alpha$-arabinosidase, arginine arylamidase, proline arylamidase, leucyl glycine arylamidase, phenylalanine arylamidase, leucine arylamidase, tyrosine arylamidase, alanine arylamidase, glycine arylamidase, histidine arylamidase, serine arylamidase, esterase, esterase lipase, lipase, valine arylamidase, cysteine arylamidase and acid phosphatase. Negative for catalase, urease, arginine dihydrolase, $\beta$-galactosidase-6-phosphate, 
Table 1. Phenotypic characteristics of strain $\mathrm{OMB} 115^{\top}$ and related type strains

Strains: 1, OMB115 ${ }^{\mathrm{T}}$; 2, B. boum JCM $1211^{\mathrm{T}}$; 3, B. thermacidophilum JCM $11165^{\mathrm{T}}$; 4, B. indicum $\mathrm{JCM} 1302^{\mathrm{T}}$; 5, B. dentium JCM $1195^{\mathrm{T}}$. All strains produce acid from D-galactose, D-glucose, D-fructose, maltose, melibiose, sucrose and raffinose. All strains are positive for $\alpha$-galactosidase, $\beta$-galactosidase, $\alpha$-glucosidase, $\beta$-glucosidase, arginine arylamidase, proline arylamidase, phenylalanine arylamidase, leucine arylamidase, tyrosine arylamidase, alanine arylamidase, glycine arylamidase, histidine arylamidase, serine arylamidase and acid phosphatase activities. None of the strains produce acid from glycerol, erythritol, D-arabinose, L-xylose, Dadonitol, methyl $\beta$-D-xylopyranoside, L-sorbose, L-rhamnose, dulcitol, inositol, D-sorbitol, methyl $\alpha$-Dmannopyranoside, $\mathrm{N}$-acetylglucosamine, inulin, melezitose, xylitol, D-lyxose, D-tagatose, D-fucose, L-fucose, D-arabitol, L-arabitol or 5-ketogluconate. All strains are negative for urease, arginine dihydrolase, $\beta$ galactosidase-6-phosphate, $\beta$-glucuronidase, $N$-acetyl- $\beta$-glucosaminidase, glutamic acid decarboxylase, $\alpha$ fucosidase, nitrate reduction, indole production, alkaline phosphatase, pyroglutamate arylamidase, glutamyl glutamic acid arylamidase, alkaline phosphatase, trypsin, chymotrypsin and $\alpha$-mannosidase. + , Positive; - , negative; $\mathrm{w}$, weak.

\begin{tabular}{|c|c|c|c|c|c|}
\hline Characteristic & 1 & 2 & 3 & 4 & 5 \\
\hline Aerobic growth & + & - & - & - & - \\
\hline \multicolumn{6}{|l|}{ Growth at/on: } \\
\hline $25{ }^{\circ} \mathrm{C}$ & + & + & + & + & $\mathrm{w}$ \\
\hline $45^{\circ} \mathrm{C}$ & + & + & + & $\mathrm{w}$ & - \\
\hline LBS agar & + & $\mathrm{W}$ & $\mathrm{w}$ & - & $\mathrm{w}$ \\
\hline DNA G $+C$ content $(\mathrm{mol} \%)$ & 53 & 60 & 58 & 60 & 61 \\
\hline \multicolumn{6}{|l|}{ API $50 \mathrm{CHL}$} \\
\hline Aesculin hydrolysis & + & - & - & + & + \\
\hline \multicolumn{6}{|l|}{ Acid from: } \\
\hline L-Arabinose & + & - & + & - & + \\
\hline D-Ribose & + & - & - & + & + \\
\hline D-Xylose & + & - & - & - & + \\
\hline D-Mannose & + & - & $\mathrm{w}$ & - & + \\
\hline D-Mannitol & + & - & - & - & + \\
\hline Methyl $\alpha$-D-glucopyranoside & + & - & + & - & - \\
\hline Amygdalin & + & - & - & + & + \\
\hline Arbutin & + & - & - & + & + \\
\hline Salicin & + & - & - & + & + \\
\hline Cellobiose & + & - & - & + & + \\
\hline D-Lactose & + & - & - & - & + \\
\hline Trehalose & + & - & - & - & + \\
\hline Starch & + & + & + & - & + \\
\hline Glycogen & + & + & + & - & + \\
\hline Gentiobiose & + & - & - & $\mathrm{w}$ & + \\
\hline Turanose & + & + & + & - & + \\
\hline Gluconate & + & - & - & - & + \\
\hline 2-Ketogluconate & $\mathrm{w}$ & - & - & - & + \\
\hline \multicolumn{6}{|l|}{ API Rapid ID 32A } \\
\hline$\alpha$-Arabinosidase & + & - & - & + & + \\
\hline Leucyl glycine arylamidase & + & + & + & + & - \\
\hline \multicolumn{6}{|l|}{ API ZYM } \\
\hline Esterase & + & + & + & - & + \\
\hline Esterase lipase & + & + & + & - & + \\
\hline Lipase & + & - & - & - & - \\
\hline Valine arylamidase & + & + & + & + & - \\
\hline Cysteine arylamidase & + & + & + & + & - \\
\hline Phosphoamidase & - & + & + & + & + \\
\hline$\beta$-Glucuronidase & - & - & - & - & + \\
\hline
\end{tabular}

$\beta$-glucuronidase, $N$-acetyl- $\beta$-glucosaminidase, glutamic acid decarboxylase, $\alpha$-fucosidase, nitrate reduction, indole production, alkaline phosphatase, pyroglutamate arylamidase, glutamyl glutamic acid arylamidase, trypsin, chymotrypsin, phosphoamidase, $\alpha$-mannosidase and $\alpha$-fucosidase. The cellwall amino acids consist of Glu-Lys-Asp-(Ala) $)_{2}$. 
The type strain, $\mathrm{OMB} 115^{\mathrm{T}} \quad\left(=\mathrm{JCM} \quad 13495^{\mathrm{T}}=\mathrm{DSM}\right.$ $\left.17777^{\mathrm{T}}\right)$, was isolated from dental plaque from hamsters fed with a high-carbohydrate diet.

\section{Acknowledgements}

We are grateful to Professor Hans G. Trüper (University of Bonn, Germany) for help with the derivation of the species epithet.

\section{References}

Becker, M. R., Paster, B. J., Leys, E. J., Moeschberger, M. L., Kenyon, S. G., Galvin, J. L., Boches, S. K., Dewhirst, F. E. \& Griffen, A. L. (2002). Molecular analysis of bacterial species associated with childhood caries. J Clin Microbiol 40, 1001-1009.

Beighton, D. (2005). The complex oral microflora of high-risk individuals and groups and its role in the caries process. Community Dent Oral Epidemiol 33, 248-255.

Caglar, E., Kargul, B. \& Tanboga, I. (2005). Bacteriotherapy and probiotics' role on oral health. Oral Dis 11, 131-137.

Chun, J., Lee, J.-H., Jung, Y., Kim, M., Kim, S., Kim, B. K. \& Lim, Y. W. (2007). EzTaxon: a web-based tool for the identification of prokaryotes based on $16 \mathrm{~S}$ ribosomal RNA gene sequence. Int J Syst Evol Microbiol 57, 2259-2261.

Crociani, F., Biavati, B., Alessandrini, A., Chiarini, C. \& Scardovi, V. (1996). Bifidobacterium inopinatum sp. nov. and Bifidobacterium denticolens sp. nov., two new species isolated from human dental caries. Int J Syst Bacteriol 46, 564-571.

Delcenserie, V., Bechoux, N., China, B., Daube, G. \& Gavini, F. (2005). A PCR method for detection of bifidobacteria in raw milk and raw milk cheese: comparison with culture-based methods. J Microbiol Methods 61, 55-67.

Einarsson, S., Josefsson, B., Moller, P. \& Sanchez, D. (1987). Separation of amino acid enantiomers and chiral amines using precolumn derivatization with $(+)$-1-(9-fluorenyl)ethyl chloroformate and reversed-phase liquid chromatography. Anal Chem 59, 1191-1195.

Ezaki, T., Saidi, S. M., Liu, S. L., Hashimoto, Y., Yamamoto, H. \& Yabuuchi, E. (1990). Rapid procedure to determine the DNA base composition from small amounts of gram-positive bacteria. FEMS Microbiol Lett 55, 127-130.

Hoyles, L., Inganas, E., Falsen, E., Drancourt, M., Weiss, N., McCartney, A. L. \& Collins, M. D. (2002). Bifidobacterium scardovii sp. nov., from human sources. Int J Syst Evol Microbiol 52, 995-999.

Jian, W. \& Dong, X. (2002). Transfer of Bifidobacterium inopinatum and Bifidobacterium denticolens to Scardovia inopinata gen. nov., comb. nov., and Parascardovia denticolens gen. nov., comb. nov., respectively. Int J Syst Evol Microbiol 52, 809-812.

Jian, W., Zhu, L. \& Dong, X. (2001). New approach to phylogenetic analysis of the genus Bifidobacterium based on partial HSP60 gene sequences. Int J Syst Evol Microbiol 51, 1633-1638.

Jordan, H. V., Keyes, P. H. \& Lim, S. (1969). Plaque formation and implantation of Odontomyces viscosus in hamsters fed different carbohydrates. J Dent Res 48, 824-831.

Kawamoto, I., Oka, T. \& Nara, T. (1981). Cell wall composition of Micromonospora olivoasterospora, Micromonospora sagamiensis, and related organisms. J Bacteriol 146, 527-534.

Kawasaki, S., Mimura, T., Satoh, T., Takeda, K. \& Niimura, Y. (2006). Response of the microaerophilic Bifidobacterium species, B. boum and B. thermophilum, to oxygen. Appl Environ Microbiol 72, 6854-6858.
Kimura, M. \& Ohta, T. (1972). On the stochastic model for estimation of mutation distance between homologous proteins. J Mol Evol 2, 87-90.

Love, R. M. \& Jenkinson, H. F. (2002). Invasion of dentinal tubules by oral bacteria. Crit Rev Oral Biol Med 13, 171-183.

Marmur, J. \& Doty, P. (1961). Thermal renaturation of deoxyribonucleic acids. J Mol Biol 3, 585-594.

Mikkelsen, L. L., Bendixen, C., Jakobsen, M. \& Jensen, B. B. (2003). Enumeration of bifidobacteria in gastrointestinal samples from piglets. Appl Environ Microbiol 69, 654-658.

Miyake, T., Watanabe, K., Watanabe, T. \& Oyaizu, H. (1998). Phylogenetic analysis of the genus Bifidobacterium and related genera based on 16S rDNA sequences. Microbiol Immunol 42, 661-667.

Munson, M. A., Banerjee, A., Watson, T. F. \& Wade, W. G. (2004). Molecular analysis of the microflora associated with dental caries. J Clin Microbiol 42, 3023-3029.

Saitou, N. \& Nei, M. (1987). The neighbor-joining method: a new method for reconstructing phylogenetic trees. Mol Biol Evol 4, 406-425.

Sakata, S., Ryu, C. S., Kitahara, M., Sakamoto, M., Hayashi, H., Fukuyama, M. \& Benno, Y. (2006). Characterization of the genus Bifidobacterium by automated ribotyping and 16S rRNA gene sequences. Microbiol Immunol 50, 1-10.

Scardovi, V. (1986). Genus Bifidobacterium Orla-Jensen. In Bergey's Manual of Systematic Bacteriology, vol. 2, pp. 1418-1434. Edited by P. H. A. Sneath, N. S. Mair, M. E. Sharpe \& J. G. Holt. Baltimore: Williams \& Wilkins.

Simpson, P. J., Ross, R. P., Fitzgerald, G. F. \& Stanton, C. (2004). Bifidobacterium psychraerophilum sp. nov. and Aeriscardovia aeriphila gen. nov., sp. nov., isolated from a porcine caecum. Int J Syst Evol Microbiol 54, 401-406.

Thompson, J. D., Higgins, D. G. \& Gibson, T. J. (1994). Clustal W: improving the sensitivity of progressive multiple sequence alignment through sequence weighting, position-specific gap penalties and weight matrix choice. Nucleic Acids Res 22, 4673-4680.

van Esbroeck, M., Vandamme, P., Falsen, E., Vancanneyt, M., Moore, E., Pot, B., Gavini, F., Kersters, K. \& Goossens, H. (1996). Polyphasic approach to the classification and identification of Gardnerella vaginalis and unidentified Gardnerella vaginalis-like coryneforms present in bacterial vaginosis. Int J Syst Bacteriol 46, 675-682.

Ventura, M., Canchaya, C., Zink, R., Fitzgerald, G. F. \& van Sinderen, D. (2004). Characterization of the groEL and groES loci in Bifidobacterium breve UCC 2003: genetic, transcriptional, and phylogenetic analyses. Appl Environ Microbiol 70, 6197-6209.

Ventura, M., Zink, R., Fitzgerald, G. F. \& van Sinderen, D. (2005). Gene structure and transcriptional organization of the dnaK operon of Bifidobacterium breve UCC 2003 and application of the operon in bifidobacterial tracing. Appl Environ Microbiol 71, 487-500.

Weisburg, W. G., Barns, S. M., Pelletier, D. A. \& Lane, D. J. (1991). $16 \mathrm{~S}$ ribosomal DNA amplification for phylogenetic study. J Bacteriol 173, 697-703.

Woese, C. R., Winker, S. \& Gutell, R. R. (1990). Architecture of ribosomal RNA: constraints on the sequence of "tetra-loops". Proc Natl Acad Sci U S A 87, 8467-8471.

Zhu, L., Li, W. \& Dong, X. (2003). Species identification of genus Bifidobacterium based on partial HSP60 gene sequences and proposal of Bifidobacterium thermacidophilum subsp. porcinum subsp. nov. Int J Syst Evol Microbiol 53, 1619-1623.

Zylber, L. J. \& Jordan, H. V. (1982). Development of a selective medium for detection and enumeration of Actinomyces viscosus and Actinomyces naeslundii in dental plaque. J Clin Microbiol 15, 253-259. 